\title{
Called into the Freedom of Christ in a Postmodern Age and the Moral Debate
}

\author{
Johann-Albrecht Meylahn ${ }^{1}$
}

(University of Pretoria)

\section{ABSTRACT}

\section{Called into the Freedom of Christ in a Postmodern Age and the Moral Debate}

Within Postmodernity we are facing tremendous ethical challenges while upholding a strong sense of freedom. In this essay I argue that this freedom is often still interpreted within a modern paradigm as an essential freedom of presence which has its roots in Neo-Platonic thinking. In Paul's letter to the Galatians there are insights to a different interpretation of the freedom we have in Christ as an eschatological freedom of calling and promise. This freedom can only be grasped in faith and is never the possession of any one individual or community, but rather a continuous challenge. It is a freedom that creates space for the other (for that, that seemed impossible) to become present (possible) and therefore it finds itself between justice (dike) and mercy - justice, as that which creates space for those who do not have space (presence), the unheard voices and the marginalised voices; and mercy which brings these unheard voices (the non-present) into being. This is the freedom to which the Cross beckons and the Resurrection inspires.

\section{INTRODUCTION}

In this essay I would like to reflect on the freedom we have in Christ, how this freedom could be interpreted in a postmodern age and what possible entry it could offer Christians into the moral debate. The theme of the essay was inspired by the letter to the Galatians, specifically the texts on freedom in chapters four and five.

Has the freedom we have in Christ, not in Western Protestant theology, been interpreted as an essential freedom or a freedom of presence which has its roots in Neo-Platonic thinking? In this essay I would like to propose an alternative reading, namely that the freedom that Paul describes here in these chapters cannot be

1 Research fellow, Department of Practical Theology, University of Pretoria. 
interpreted as a Neo-Platonic freedom, but rather as an eschatological freedom of calling and promise. Eschatological freedom is not an essential freedom nor a freedom of presence discovered in the self, but a freedom which calls one into the promise of the impossible ${ }^{2}$. The freedom that Paul says we have in Christ is a freedom based on the covenant with Abraham which is a covenant of calling and promise.

I believe that this question of freedom we have in Christ is pivotal in the church's discussions, in a time where questions on subjectivity/identity and normativity are being debated in and outside the church. Therefore, in the postmodern context, the question concerning the freedom we have in Christ needs to become central, as I believe that the answer to the questions, Who are we as Christians (identity and subjectivity)? and By what norms do we live? depends on the interpretation of the freedom we have in Christ ${ }^{3}$.

Is the freedom or for that matter the identity which we have as church and as believers, something essential, something of subjective presence, or is it a calling to an impossible openness of the promise which is eschatologically deferred? I believe that if the church can ask this question it will be able to make a tremendous and valuable contribution to the ethical challenges we are facing in a global and postmodern age. In South Africa the Government has called on religious leaders to help compile a Moral Charter to augment the Freedom Charter and the Bill of Rights. This move of the Government highlights the two poles of the moral/ethical debate, namely freedom and rights versus norms and values. This debate can only be effectively addressed if we take the developments with regard to identity and subjectivity seriously. The moral debate in and outside the church about issues such as homosexuality has come to a dead end with two seemingly conflicting poles, namely those in support of freedom and individual rights and those supporting norms and "traditional" values. In this essay I believe that a reinterpretation of freedom and of norms is necessary if the church wants to face these moral and ethical issues within postmodernity.

2 "Now, you, brothers, like Isaac, are children of promise" (Gl 4:28).

3 "It is for freedom that Christ has set us free" (Gl 5:1).

"You, my brothers, were called to be free" (Gl 5:13a). 
We are living in an age where on the one hand the philosophers of postmodernity tell us that there are no universals or absolutes and that all is relative to history and context and thus the whole question of norms is challenged. They also argue that the subjective self can no longer be understood as an essential being, but a creation of communicative praxis or as Heidegger argued a Being as a being-inthe-world (Heidegger 1996). This understanding of Being challenges the understanding of a subject as a being who has essential rights or essential freedom as an individual. Yet, while philosophically norms and essential subjectivity are being questioned, there is on the other hand in every day politics and religion a revival of fundamentals, universals and absolutes. This revival of fundamentals and absolutes finds expression in rise of fundamentalist groups within various religious and political traditions, but also in humanity's search for norms and values which are then universalised by conservative politics. Could the re-election of conservative political leaders and the election of a pope who is being regarded by many as conservative, be interpreted as expressions of humanity's inability to live in the freedom of Christ? Yet there are many church leaders and religious groups that would argue that it is the responsibility of the church to provide humanity with the security and comfort of norms and absolutes in an uncertain and confused age. Heidegger already criticised this tendency in humanity to always seek security and comfort rather than live on the edge of the abyss (Heidegger 1985).

In this political, moral, social, cultural and religious context the church needs to reflect on the freedom to which we are called. It is this question that I would like to reflect on in this essay.

\section{THE POSTMODERN DEMISE OF NORMS, ABSO- LUTES AND THE ESSENTIAL SUBJECT}

The post in postmodern I believe is the challenging voice of deconstruction, which deconstructs some of the fundamental values and beliefs of modernity. Yet this deconstruction is an autodeconstruction from within the story of modernity itself and thus it is a very responsible deconstruction as it takes the tradition seriously ${ }^{4}$.

4 Martin Heidegger who has been recognised as one of the great thinkers of postmodernity in his work, Being and Time, worked within the paradigms of modernity seeking to answer the ontological questions, and in his exploration of these questions both from a classical Greek perspective as well as modern / Enlightenment perspective, discovered flaws, breaks and cracks in these 
The modern (positivist) fundamentals that are being challenged are the following: that knowledge is certain, knowledge is objective and knowledge is inherently good. These epistemological assumptions arose out of the Enlightenment and have determined modernity. The seed that would later challenge these basic assumptions of modernity and positivism was already planted by one of the greatest thinkers of the Enlightenment namely Kant. Kant in his book, The Critique of Pure Reason, already argued that the self cannot discover preexisting order in nature, but projects such order creatively upon reality.

"Since ... nature's conformity to law rests on the necessary linking of phenomena in experience, without which we could not know any objects of the world of the sense, in other words, such conformity rests on the original laws of the intellect, it sounds strange at first, but it is none the less true when I say in respect of these laws of the intellect: the intellect does not derive its laws (a priori) from nature but prescribes them to nature" (Kant 1949b:91).

This Kantian idea that the self does not through the power of Cartesian rationality discover order in the world, but imaginatively prescribes order onto reality, already shook at the foundations of the rational self and made way for the imaginative, intuitive and creative self of Husserl and Romanticism. The rational self scrutinising objective reality and discovering order and meaning in this objective reality was replaced by a imaginative, intuitive and creative self who prescribed order on reality. It was no longer rationality which linked the subjective self to the objective reality but intuition. The seed was sown that began questioning these assumptions as the search for certain and objective knowledge continued. Knowledge/truth was still sought either rationally or intuitively and it was understood to be certain, objective and inherently good.

arguments. Jacques Derrida, answering a question with regards to deconstruction and tradition, said: "It [deconstruction] is an analysis which tries to find out how their thinking works or does not work, to find the tensions, the contradictions, and the heterogeneity within their corpus. What is the law of this self-deconstruction, this "auto-deconstruction"? Deconstruction is not a method or some tool that you apply to something from the outside. Deconstruction is something which happens and which happens inside; there is a deconstruction at work within Plato's work, for instance" (Derrida 1997:9). 
Nietzsche challenged these ideas about certain, objective and inherently good knowledge. Nietzsche strongly challenged the positivist assumption that knowledge is good. Responding to the question, What is truth? Nietzsche responded in the following way:

"a mobile army of metaphors, metonyms, and anthropomorphisms - in short, a sum of human relations, which have been enhanced, transposed, and embellished poetically and rhetorically, and which after long use seem firm, canonical, and obligatory to a people: Truths are illusions about which one has forgotten that this is what they are: metaphors which are worn out and without sensuous power; coins which have lost their pictures and now matter only as metal, no longer as coins... To be truthful means using the customary metaphors - in moral terms: the obligation to lie according to a fixed convention, to lie herd-like in style obligatory for all" (Nietzsche 1976:46-47).

For Nietzsche knowledge/truth is not something that a subjective self discovers in the objective world, but rather his/her subjective will to power which is projected onto reality. "The man in this condition transforms things until they mirror his power - until they are reflections of his perfection" (Nietzsche 1968:72). Thus the inherent goodness of knowledge was challenged by Nietzsche's argument that knowledge is nothing else but a reflection of humanity's will to power. These thoughts were later taken up by Habermas who understood knowledge as that which comes into existence through specific group interests.

Other thinkers like Wittgenstein also challenged the idea that knowledge is certain and objective. He challenged the idea that a subject could gain knowledge from an objective reality. What links a subject to reality is language and humanity can never escape the realm of language and therefore there is no objective access to reality. Thus it can also be said that all knowledge is within the realm of language and can never escape language. Wittgenstein wrote in Tractatus Logico-Philosophicus: "5.6 The limits of my language mean the limits of my world" (Wittgenstein 1961:56).

Wittgenstein understood language to be a picture of reality, but keeping in mind that all we have access to, is the picture. "2.11 A picture presents a situation in logical space, the existence and nonexistence of states of affairs" (Wittgenstein 1961). The language picture reaches out trying to capture reality. "2.1515 These 
correlations are, as it were, the feelers of the picture's elements, with which the picture touches reality" (Wittgenstein 1961).

For this picture theory to be useful Stenius (Stenius 1960:90) argues that the pictures need to be understood as isomorphic pictures. Isomorphic pictures are pictures where the following conditions are met:

1. The categorical structure of both pictures needs to be the same.

2. There must be a one to one correspondence between the elements of each of the pictures.

The basic a priori assumption of the relationship between language and reality is accepted to be isomorphic. However, humanity has no way of discovering if this is the case, because all we have direct access to is the picture (language) and not reality, therefore nobody can with certainty prove that language is isomorphic to reality. Therefore Wittgenstein argues that, " 2.221 What a picture represents is its sense" (Wittgenstein 1961), in other words the sense of a picture or a proposition is internal to the picture and proposition (Mounce 1981:23).

Derrida's concept of differrence continues this argument that between reality and language there is always an unbridgeable gap which always remains open. This unbridgeable gap between language and reality, between language and closure in knowledge, brings about the movement from epistemology to hermeneutics. If the gap is unbridgeable then it is no longer about subjective self knowing or discovering objective and certain truth, but knowledge depends on interpretation because that gap can never be filled with certain knowledge, but only with an interpretation that seeks to bridge the gap. This gap is governed by différence. The notion of objective, certain and inherently good knowledge has been replaced with various models of interpretation (hermeneutic) and I believe that this shift is what is central in the movement from modern to postmodern.

In a similar way that epistemology was deconstructed so also was the subjective self deconstructed. As Calvin Schrag argues that in the discussion of the topic of subjectivity it is "our historical destiny to begin with Descartes for it is he who invented the modern concept of the subject as the source and center for his philosophy of mind" (Schrag 1985:26). This modern invention of the subject is 
based on an argument for the ego-cogito and it proceeds within the context of systematic doubt and epistemic requirements of intuition and deductive inference. All truths which are based either on experience or rationally formulated truths can be doubted, except the 'fact' that somebody is doubting. In a similar vein one can doubt away all reality, except the 'fact' that the person doubting away reality is doubting. The conclusion of this systematic doubt delivers an indubitable cogito - a cogito which is intuitively grasped in the very act of thinking reflectively directed to itself. "Thought presupposes a "who" that is thinking; doubt presupposes a "who" that is doubting" (Schrag 1985:26).

There is a certain similarity between the process of Cartesian doubt and the deconstructive journey as both peal away layers of philosophically constructed reality. In a certain sense the doubting subject of the Cartesian process is replaced with the deconstructing subject of deconstruction. Therefore it can be argued that a certain trace of subjectivity remains necessary to the very process of deconstruction, as there is a 'who' who is deconstructing. But what kind of subjectivity is this? Jacques Derrida, once asked about the role of the subject within deconstruction, responded in the following way:

"The subject is absolutely indispensable. I don't destroy the subject; I situate it. That is to say, I believe that at a certain level both of experience and of philosophical and scientific discourse one cannot get along without the notion of subject. It is a question of knowing where it comes from and how it functions" (Derrida 1970:271).

The subject within deconstruction is not completely lost, but what kind of subject can one speak of in postmodernity? The question is still "who" is it that deconstructs. Maybe the question needs to change or maybe our pre-understanding that accompanies the question needs to change. What are we looking for when we are looking for the "who"? Are we still looking for a residuum, something substantial that is left after deconstruction? Are we looking for an essential centre of consciousness? Or maybe we are looking for a stable presence that supports the stream of thoughts, doubts and questions? "This concept of mind, however, still called upon the classical doctrine of substance to provide the consciousness 
with a stable support, an abiding and ever-present ego, an Archimedian point of certainty" (Schrag 1985:27).

This quest is still within the paradigm of metaphysicoepistemological space and I believe a different paradigm is necessary, in other words a different pre-understanding of what we are looking for to give content to the "who". The alternative paradigm would be to ask this question in the context of conversations, habits, skills and institutional involvements that describe the hermeneutical space of communicative praxis or the narrative understanding of self which incorporates this hermeneutical space. The self is no longer defined by propositions which can be doubted, which can be deconstructed, but by the narrative describing the history of social practices. "One can always defer theoretical judgments about oneself, but in the meantime one continues to speak, act, work, play, and assume social roles. This is the domain of communicative praxis, and it is here, we suggest, that we look for a possible restoration of subjectivity" (Schrag 1985:27). The subjective self has been deconstructed as a cognitive center in an epistemological space and undergoes a hermeneutical selfimplicature in the space of communicative praxis.

Therefore freedom can no longer be understood within the context of the traditional interpretation of the subjective self, but needs to be interpreted within the context of communicative praxis.

\section{IS POSTMODERNITY A NEO-PLATONIC TRAGEDY?}

Is postmodernity the tragic end of the classical search for the essential substance? Is it the end of the Cartesian indubitable fundament? Postmodernity tells us that this search is in vain, but this statement is in itself an absolute. Yet the search continues and it will always continue because the question is: can we live with the fact that our findings are relative to the findings of others in different contexts and from different times? Is this all that we are left with: a non-absolute absolute or a non-foundational foundation, or is there a different story to tell?

Maybe there is a different story which can function as an alternative to the classical Platonic and Neo-Platonic or modernist story, namely a story that places this non-absolute absolute into a different context. This story is not embedded in the context of 
science, metaphysics, ideology or even religion, but in the context of faith $^{5}$.

In the turn or return to faith's story I will turn to the father of three of the world's faiths, namely Abraham and the covenant of promise and its postponed eschatological fulfilment. I turn to Abraham because it is in the context of the promise made to Abraham that Paul understands the call to freedom. The call to freedom in the Galatians text needs to be interpreted in the context of promise, rather than in the context of freedom, understood as a characteristic which is inherently and essentially part of the substance of the individual. The Reformers and especially Martin Luther $^{6}$ I believe understood this freedom as an essential characteristic belonging to the Christian. In other words, it is something that is directly connected to the Being of being a Christian. Freedom is often understood as a basic right, as an experiential characteristic or as something that can be intuitively discovered and incorporated into one's Being. From the previous section where I discussed the demise of the subjective self this understanding of freedom seems impossible. In the next section I would like to journey a different path and that is that the freedom to which the Christian is called to is not an essential freedom of Being, but rather a freedom given and hoped for in faith, namely the freedom of calling and the calling of promise.

\section{AN IMPOSSIBLE PROMISE: THE CALLING INTO ESCHATOLOGICAL OPENNESS AND THE FREEDOM OF CHRIST CRUCIFIED}

The journey of trying to discover the meaning of the freedom we have in Christ begins with Abraham according to Paul in the

5 When I refer to faith, I am not referring to a specific faith tradition, but faith in contrast to science, knowledge, ideology and thus also in contrast to metaphysical religion.

6 Luther in his well known work, „Die Freiheit eines Christenmenschen”, argues the double nature of the Christian: „Ein Christenmensch ist ein freier Herr über alle Dinge und niemand untertan; Ein Christenmensch ist ein dienstbarer Knecht alle Dinge und jedermann untertan", and this argument is based on the dual nature of the believer. „Zum andern. Diese zwei widerständigen Reden von der Freiheit und Dienstbarkeit zu vernehmen, sollen wir gedenken, daß ein jeglicher Christenmensch zweierlei Natur ist, geistlicher und leiblicher". 
Galatians text. Through Christ's Spirit believers become descendents of Abraham. Christians are descendents of the one who embarked on an impossible journey with only a calling and a promise. This promise was not a universal promise. It was not even a promise that could be rationally verified, but it was an impossible promise and would have sounded as utter nonsense to any other ear, but to the ear of Abraham. Yet Abraham embarked on a journey of faith. He was called onto this journey by this promise of the impossible. Paul links the Christian's call to freedom to this call by a promise of the impossible.

The longer Abraham journeyed the more impossible the promise became. It seemed nonsensical and even absurd to continue believing that a great nation would be born of a barren woman. One could argue that Abraham was determined and could be characterised as a person of promise, but was this promise something that he had, was it something that was inherently part of his Being or was it something continually beyond him? To answer these questions let us turn to Heidegger and his understanding of Being.

Heidegger in his book, Sein und Zeit, argues for authentic Dasein. This authentic Dasein can be understood as free Dasein. But what is this Dasein? In Heidegger's "Vier Seminare" (Heidegger 1977:73, 82-87) the seminar notes mark off three different stages on the path of thought. The first stage was to reflect on the meaning of the Being of beings. This path was abandoned because the meaning of Being was too closely tied up with the structure of transcendental subjectivity (Caputo 1993:30). The second step was to reflect on the "truth" of Being. This second step was a historical search with the hope that in some distant past there was an epoch where people experienced the "truth" of Being. This line of thinking is very essentialist as if there is one singular "truth" of Being. This is where many argue that Heidegger turned from his original path of deconstructing tradition to questions towards mythology, namely the mythology of the "truth" of Being found in the early Greek philosophy.

The final stage along this path of thought is to be found in locating the "place" of Being. This is a search for the "open space within which Being and time play themselves out, and here the guideword is neither meaning nor truth but Ereignis" (Caputo 
1993:30). This opening can be called a-letheia ${ }^{7}$. It is in this open space (a-letheia) that all essentialist and absolute thinking are challenged by the multiplicity and the unfolding of many different even contradictory meanings and truths of Being across the epochs. None of these epochs can be privileged to be more truthful or to have a better understanding of the meaning of Being.

"But what this demythologized Heidegger has in fact accomplished is a description of every epoch in terms of a structurally necessary withdrawal, a moment of lethe, in which the open space itself, the opening up of the open within which a given epoch happens, withdraws from view in order that what is granted in that epoch may come to presence. That means that every epoch is equally epochal, inhabited by the structure of withdrawal, and no epoch can be privileged" (Caputo 1993:31).

It is in this open space that Being becomes present thus Being can be understood not in essentialist terms, but as a process of unconcealment (a-letheia). One can also argue that un-concealment can be interpreted as liberation from concealment thus Being can be interpreted as liberation, making beings free to be present. Thus it can be argued that truth (aletheia) and freedom are inseparably intertwined (Richardson 1986:163). Freedom is thus not something essential to being, but is part of the process of Being. What must be remembered is that this un-concealment (a-letheia) is simultaneous concealment, therefore no being can come fully and finally into presence. Thus this liberation is limited and relative to the open space that gave it birth and which has withdrawn.

Heidegger understands Dasein as human-Being. In other words Dasein is when a person has become aware of his/her Being and this awareness for Heidegger is an awareness of being-in-the-world.

7 There are two ways of speaking of aletheia, namely aletheia and aletheia. In the first sense (aletheia) it means un-concealment/revealing, phainesthai. This first sense is taken from the Greek understanding of the words: phainesthai and aletheia. It is within the context of these terms that the early Greeks began to understand Being. A-letheia means that "granting which bestows presence in its phenomenality, that opening which, always out of sight, is that within which every epoch of presence takes place" (Caputo 1993:23). Aletheia means the a-lethic process which grants epochs presence. The first sense of the word means presence and the second means that which grants presence. A-letheia is that which grants aletheia presence. 
Dasein thus cannot be described in terms of substance, but only of a process (Richardson 1986:165). Dasein is in-the-world and this inthe-world means that Dasein is related to many other beings also inthe-world. Dasein can understand its Being in-the-world either with reference to the other beings in-the-world ${ }^{8}$ or with reference to an understanding of Being. Heidegger continues that Dasein becomes aware of various forms of finality and also of death and this causes anxiety, but anxiety helps Dasein become aware of his/her being inthe-world, but anxiety also opens Dasein to the possibilities of the world. Thus anxiety places Dasein before a choice to either be authentic (open to the world and Being) or inauthentic (determined by the other beings-in-the world). In other words, authentic Dasein can be interpreted as Dasein which has accepted the finitude and relativity of Being, thus standing at the edge of the abyss, of the opening space that makes Being possible, and then withdraws - the abyss that says nothing and that is an impossibility, but calls Being to authentic liberated Dasein. It is here at the abyss, the open space/a-letheia which withdraws to allow being to be revealed and then by its withdrawal conceals what has been revealed, that freedom needs to be situated.

After journeying with Heidegger and interpretations of Heidegger, freedom was situated at the abyss, the open space namely a-letheia - a space which is a-historical, which is without meaning and content and yet which calls us to authentic Being and thus calls us into liberation. It opens the space for the liberation of Being from concealment.

If we want to place this freedom in a story then I believe both the story of Abraham and the story of the Cross are most appropriate.

I do not want to compare the Cross or Abraham's promise with a-letheia. That would be impossible, because then a-letheia is no longer an open space, it is no longer an unbridgeable abyss, but it has content and is bound to a specific interpretation. It is rather the other way round - a-letheia makes it possible to tell these stories of Abraham and of Christ crucified. Maybe they are even stories which try to understand and interpret the freedom of a-letheia, but the

8 This Being determined by the other beings in-the-world Heidegger describes as "fallenness" (Being and Time). 
moment they are told or the moment the story begins that which it speaks about withdraws from the story into concealment.

Abraham's promise, in the context of Heidegger's understanding of Dasein's everydayness and fallenness (Being defined and determined by that which is at hand in the everydayness of Being-in-the-world), seems utterly absurd: to leave home and family and embark on a journey with only a promise and to add to that a promise that became more and more absurd as time eroded the possibilities of its fulfilment. Abraham's freedom was not defined by the possible (by that which is present), but by the impossible ( $a$ letheia, that which grants space for the impossible possibility, in other words the opening for possibility/presence). Paul relates the freedom we have in Christ to this freedom of Abraham's promise. This is the freedom not of the possible (of the present), not an essential or subjective freedom, but the freedom of the impossible which grants space for the impossible to be revealed as possible. In a sense the story of the Cross of $\mathrm{Christ}^{9}$ is also a deconstruction of the possible / the present (the law) and thus the opening of the impossible, which is the resurrection promise of a new impossible presence. This thinking cannot take place within science or even religion, but is a matter of faith, as only faith can see the possibility of the impossible. Only faith can grasp the impossibilities which $a$ letheia opens.

Is this the freedom Paul speaks of? Then this freedom has very little to do with rights of an individual, but has to do with living on the borders of the possible and questioning the possible (the nomos). This questioning is motivated by a-letheia / the promise / the Cross, which challenges the presence and the law of the possible by the abyss of the impossible which makes the impossible possible and opens the space for its presence.

9 Jürgen Moltmann (1974:128-145) discusses how the cross challenges (deconstructs) the following: the law by Christ the blasphemer, authority by Christ the rebel and God/ideology/idolatry by Christ the godforsaken. The Cross challenges the possible of the presence, namely that which is held in place by law, authority and ideology and thus opens the space for the impossible. 


\section{CONCLUDING REMARKS}

In conclusion I would like to return to the praxis of the church in a time where humanity is seeking norms (laws that give authority and define presence and possibility). The church is caught in the debate between rights and the freedom enshrined in these rights and norms which set the boundaries to this freedom. For example the debate about homosexuality is a debate about a certain understanding of freedom and rights as well as a certain understanding of norms. I hope to have shown that both these interpretations and understandings are in need of deconstruction. Once we understand the freedom of Christ as living on the boundaries of norms, challenging these norms with the impossibility of grace revealed in the Cross and the promise of the resurrection, then I believe this debate is shifted away from concepts of freedom and norms to interpretations of justice and mercy. This shift makes sense if justice is interpreted as Heidegger ${ }^{10}$ interpreted Anaximander's understanding of justice as dike: that which allows moments of presence to while away (Caputo 1993:31), in other words justice as that which understands presence and norms not to be universal and absolute, but temporal and even in the temporality not absolute (there is always still concealment in every un-concealment of presence). Injustice is adikia which "results from the stiff-necked persistence of presence, which refuses to go under, to give way to another, to give its place to another" (Caputo 1993:31). A-dikia is the refusal to budge on norms to make space for another. It is where authority of an epoch asserts itself as absolute (Heidegger 1971:357, 368). Injustice is thus giving absolute authority to a certain understanding of Being or to an un-concealment (aletheia) of a certain presence. Justice thus needs to be understood in the context of the freedom of a-letheia, in other words that which makes space for aletheia. This sentiment of justice I believe is echoed in the words of the prophets who challenged the presence and norms of Israel's ideology with the coming into presence of those marginalised namely the widow, orphan and stranger, who, through the call of the prophet, are given a space to be-come present and this

10 In this essay I have made extensive use of Heidegger and his interpretation of Being and even justice, although he himself sought essence in a historical or trans-historical epoch, namely the early Greeks, and therefore committed an injustice by giving privilege to one epoch over others. 
is the justice God seeks. This is the justice that I believe the New Testament calls Christians to.

The Bible has this interpretation of justice (dike) as it continually creates space for the unheard stories of the poor, the widow, the stranger, the outsider and the foreigner and this space is called mercy. The New Testament specifically forces upon the dominant nomos, the dominant presence and the dominant epoch, the unheard marginalised stories of the poor, the crippled, the lame and the outsiders. The New Testament creates space for the stories of the marginalised who have been unjustly (adikia) not given space to be heard. The other presence and the Being of the other who has not been given a platform to be present is given a voice in the New Testament and that is justice (dike) understood as mercy.

For the church in the postmodern context a re-interpretation of freedom and of norms (presence) is required and maybe the best context for that is the context of justice (dike) and mercy. The call into the freedom of Christ is a call to justice and mercy and it is an appropriate context to face the ethical challenges of postmodernity.

\section{Consulted literature}

Caputo, J D 1993. Demythologizing Heidegger. Bloomington, Indianapolis: Indiana University Press.

Derrida, J 1970. 'Structure, Sign, and Play' in Macksey R \& Donato E (eds). The Languages of Criticism and the Science of Man: The Structuralist Controversy. Baltimore: The John Hopkins Press.

-, 1997. Deconstruction in a Nutshell: A Conversation with Jacques Derrida. Edited by John D Caputo. New York: Forham University Press.

Heidegger, M 1971. Gesamtausgabe, B 29/30. Holzwege. Frankfurt: Klostermann.

-, 1977. Vier Seminare. Translated by C. Ochwadt. Frankfurt: Klostermann.

-, 1985. Gesamtausgabe, B 61 Phänomenologische Interpretation zu Aristoteles: Einführung in die phänomenlogische Forschung. Frankfurt: Klostermann.

-, 1996. Being and Time: A Translation of Sein und Zeit. Translated by Joan Stambaugh. New York: State University of New York Press.

Kant, I 1949. Prolegomena to Every Future Metaphysics that May be Presented as Science, in Friedrich, C J (ed), The Philosophy of Kant. New York: Modern Library

Luther, M Martin Luther's Ausgewählte Schriften. Zweite Auflage. Berlin: Askanischer Verlag. 
Moltmann, J 1974. The Crucified God. Translated by R A Wilson and J Bowden. London: SCM Press.

Mounce, H O 1981. Wittgenstein's Tractatus: An Introduction. Oxford: Basil Blackwell.

Nietzsche, F 1968. Twilight of the Idols. London: Penguin Books.

Nietzsche, F 1976. On Truth and Lie in an Extra-Moral Sense, in Kaufmann, W (ed) The Portable Nietzsche. New York: Penguin Books.

Richardson, W 1986. "Heidegger and the Quest for Freedom" in Kockelmans J $\mathrm{J}$ (ed). A Companion to Martin Heidegger's "Being and Time”. Washington DC: Center for Advanced Research in Phenomenology \& and University of America Press.

Schrag, C O 1985. Subjectivity and Praxis at the End of Philosophy in Silverman H J \& Ihde H (eds). Hermeneutics and Deconstruction. New York: State University of New York Press.

Stenius, E 1960. Wittgenstein's Tractatus A Critical Exposition of It's Main Lines of Thought. Oxford: Basil Blackwell.

Wittgenstein, L 1961. Tractatus Logico-Philosophicus. London: Routledge \& Kegan Paul. 